\title{
Early diagnosis of spontaneous heterotopic pregnancy successfully treated with laparoscopic surgery
}

\author{
Celia Soares, Ana Maçães, Mariana Novais Veiga, Marta Osório
}

Obstetrics and Gynecology, Centro Hospitalar de Vila Nova de Gaia Espinho EPE, Vila Nova de Gaia, Portugal

\section{Correspondence to}

Dr Celia Soares;

celia.cmsoares@gmail.com

Accepted 16 October 2020

\section{DESCRIPTION}

An 18-year-old nulliparous woman presented to our emergency department with a history of severe hypogastric pain with vomiting for 2 days and unknown date of last menstrual period. The patient had no relevant medical history and she was not taking any medication, including ovulation inductors. On clinical examination, she was haemodynamically stable, reported pain on palpation of the left iliac fossa but had no rebound tenderness. Transvaginal ultrasound revealed an evolutive 6 weeks' gestational age intrauterine pregnancy (IUP; figure $1 \mathrm{~A}$ ) and a non-cystic extraovarian mass $(58 \times 35 \mathrm{~mm}$; figure $1 \mathrm{~B}, \mathrm{C})$ with surrounding fluid in the left adnexa (figure 1). Two corpus luteum cysts were seen, one in each ovary. The blood results were normal and the human chorionic gonadotropin levels were 15 $797 \mathrm{mIU} / \mathrm{mL}$.

A heterotopic pregnancy (HP) was suspected, so the patient was admitted. In the first hours of hospitalisation, despite remaining haemodynamically stable, the patient had worsening abdominal pain, presenting at this time point with rebound tenderness and anaemia (haemoglobin $102 \mathrm{~g} / \mathrm{L}$ ). Ultrasound reassessment revealed a moderate amount of free fluid, consistent with the acute blood loss noted in the dropping haemoglobin.

An exploratory laparoscopy was performed and revealed a moderate haemoperitoneum, an open left fallopian tube in its distal portion, and a clot and trophoblastic tissue in the pouch of Douglas (figure 2). A left salpingectomy was carried out. The pathological examination confirmed the diagnosis of tubal ectopic pregnancy (EP). She was discharged on day 2. The remaining pregnancy was uneventful. The patient delivered a healthy

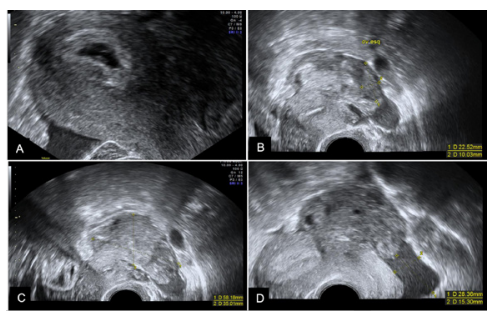

Figure 1 Transvaginal ultrasound image of an evolutive 6 weeks' intrauterine pregnancy (A). Left ovary $(23 \times 10 \mathrm{~mm})(B)$ and, next to it, a non-cystic heterogeneous mass $(58 \times 35 \mathrm{~mm})(C)$ with moderate free fluid (D).

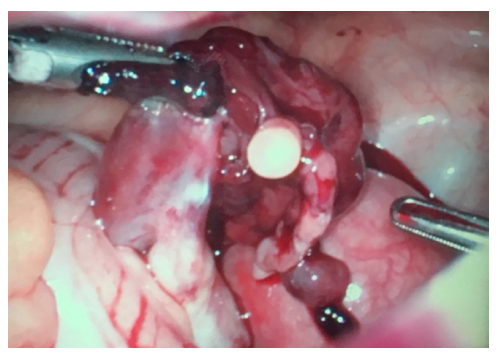

Figure 2 Left fallopian tube open at its distal portion with clot and trophoblastic tissue in the pouch of Douglas.

live baby girl at 39 weeks by vaginal delivery following a spontaneous labour.

$\mathrm{HP}$ is defined as the coexistence of at least two pregnancies in different implantation sites and its incidence in spontaneous pregnancies is estimated to be $1 / 30000 .{ }^{1}$ Predisposing risk factors include previous history of EP, tubal surgery, pelvic inflammatory disease, use of an intrauterine device, in vitro fertilisation in the current pregnancy, in utero diethylstilbestrol exposure and smoking. ${ }^{23}$

The main symptoms of HP are abdominal pain, adnexal mass, peritoneal irritation and an enlarged uterus, ${ }^{1}$ which can mimic other gynaecological causes (miscarriage, EP, IUP with haemorrhagic corpus luteum and adnexal torsion) and non-gynaecological ones (appendicitis, cholecystitis, bowel obstruction or pancreatitis). ${ }^{4}$ Due to these unspecific clinical symptoms, the diagnosis of HP is often delayed and only made after a ruptured $\mathrm{EP},{ }^{1}$ which is associated with a considerable risk of maternal morbidity and mortality (0.50 per 100000 live births). ${ }^{45}$ Despite its low sensitivity $(33 \%)$ in the detection of HP, transvaginal ultrasound is the gold standard for diagnosis. ${ }^{67}$ Although ultrasound evaluation of an early gestation should include the adnexa, the diagnosis of an IUP often leads to the mistaken exclusion of the hypothesis of a concomitant EP. ${ }^{4}$

We present a rare case of a spontaneous HP in a woman with no obvious predisposing risk factors. Patients with no risk factors account for a minority of the cases of $\mathrm{HP}^{3}{ }^{3}$ Despite the low suspicion index, transvaginal ultrasound with systematic evaluation of the adnexa allowed an early diagnosis of such a rare case of HP. There are several cases reported of HP where EP was not detected initially. ${ }^{78}$ A key insight of the presented 


\section{Patient's perspective}

At first, I was very happy to know that I was pregnant as it was a desired pregnancy. I was far from imagining what was to come next. I never thought that from an emotional and physical point of view, it would be so painful. I had never experienced anything like this before in all my life. When it was told to me that I would have to undergo a surgical procedure, I was quite scared and somewhat afraid. From that moment on, I cannot remember anything. I must say that after waking up, I felt much better, without pain, but with some fear of what might still happen. Fortunately, everything went well and the pregnancy went smoothly. Despite the huge scare that was in the early hours, everything ended up going normal, and nowadays, fortunately, I have an extremely healthy, active child with no health problems or disabilities. Regarding the medical team in general, but particularly the team responsible for the operation, I would like to emphasise that they were extremely competent, attentive and especially very careful. I leave a huge thanks to everyone and I would also like to highlight the nurses and health assistants because they have had a fundamental role in my recovery.

\section{Learning points}

- Heterotopic pregnancy (HP) is a life-threatening, difficult-todiagnose condition. To exclude a possible ectopic pregnancy, it is important to evaluate the adnexa carefully through ultrasound, even if an intrauterine gestational sac is already confirmed and even if there is no apparent risk factor.

- HP tends to be overlooked after confirming an intrauterine pregnancy.

- When a diagnosis is established on time, the number of pregnancies that reach term after treatment is significant. report is that careful adnexal ultrasound assessment mitigates the risk of missing an EP in the presence of an IUP.

A timely diagnosis of HP offers more treatment options to patients. In the reported case, the patient underwent a laparoscopic salpingectomy. The uterus was not manipulated, to preserve the IUP. This is considered the safest treatment approach by most authors. ${ }^{57}$

Contributors CS acquired the data and wrote the manuscript. AM, MNV and MO provided critical revision for the manuscript.

Funding The authors have not declared a specific grant for this research from any funding agency in the public, commercial or not-for-profit sectors.

Competing interests None declared.

Patient consent for publication Obtained.

Provenance and peer review Not commissioned; externally peer-reviewed.

\section{REFERENCES}

1 Reece EA, Petrie RH, Sirmans MF, et al. Combined intrauterine and extrauterine gestations: a review. Am J Obstet Gynecol 1983;146:323-30.

2 Ankum WM, Mol BW, Van der Veen F, et al. Risk factors for ectopic pregnancy: a metaanalysis. Fertil Steril 1996;65:1093.

3 Talbot K, Simpson R, Price N, et al. Heterotopic pregnancy. J Obstet Gynaecol 2011:31:7-12.

4 Ramalho I, Ferreira I, Marques JP, et al. Live birth after treatment of a spontaneous ovarian heterotopic pregnancy: a case report. Case Rep Womens Health 2019;24:e00144.

5 Eom JM, Choi JS, Ko JH, et al. Surgical and obstetric outcomes of laparoscopic management for women with heterotopic pregnancy. J Obstet Gynaecol Res 2013;39:1580-6.

6 Webster K, Eadon H, Fishburn S, et al. Ectopic pregnancy and miscarriage: diagnosis and initial management: summary of updated NICE guidance. BMJ 2019;367:16283.

7 Gibson KR, Horne AW. Ruptured heterotopic pregnancy: an unusual presentation of an uncommon clinical problem. BMJ Case Rep 2012;2012. doi:10.1136/bcr-2012007423. [Epub ahead of print: 28 Nov 2012].

8 Fatema N, Al Badi MM, Rahman M, et al. Heterotopic pregnancy with natural conception; a rare event that is still being misdiagnosed: a case report. Clin Case Rep 2016:4:272-5.

Copyright 2020 BMJ Publishing Group. All rights reserved. For permission to reuse any of this content visit

https://www.bmj.com/company/products-services/rights-and-licensing/permissions/

BMJ Case Report Fellows may re-use this article for personal use and teaching without any further permission.

Become a Fellow of BMJ Case Reports today and you can:

- Submit as many cases as you like

Enjoy fast sympathetic peer review and rapid publication of accepted articles

- Access all the published articles

- Re-use any of the published material for personal use and teaching without further permission

Customer Service

If you have any further queries about your subscription, please contact our customer services team on +44 (0) 2071111105 or via email at support@bmj.com.

Visit casereports.bmj.com for more articles like this and to become a Fellow 